Revista Iberoamericana. Vol. LXVI, Núm. 192, Julio-Septiembre 2000, 601-616

\title{
MATERNIDADE, MITO E IDEOLOGIA NA FICÇÃO DE LYA LUFT
}

\author{
POR \\ Eva Paulino Bueno \\ Penn State University
}

\author{
Ser mãe é desdobrar fibra por fibra \\ O coração! \\ .... \\ Ser mãe é padecer num paraíso!
}

Coelho Neto

Em seu comentário autobiográfico Circonfession, há um momento em que o filósofo francês Jacques Derrida, tentando lidar com a longa e mortal doença de sua mãe, escreve: "Hurry, the memoirs before the thing happens ... rushing ahead, I confess my mother, one always confesses the other, I make her speak in me, before me” — “ Depressa, as memórias antes que a coisa aconteça. .. indo adiante, eu confesso minha mãe, todos sempre confessam a mãe, eu a faço falar em mim, antes de mim”. ${ }^{1}$ Esta passagem é extremamente pertinente à minha discussão de romances dos Lya Luft porque neste trecho um filho, Derrida, reconhece que ele fala pela mãe como se ela já estivesse morta; ele se apropria da voz da mãe e fala por ela. Confessando a mãe, Derrida — homem e filho— quebra as barreiras de tempo e gênero. Em sua confissão, ele pode retroceder e avançar na vida de sua mãe, tomar liberdades e fazer afirmações ou negações, já que a mãe está encrustrada em um futuro perfeito do qual ele — filho e homem- a recuperará para seu próprio discurso sem que ela — mulher e mãe- possa dizer nada. Então, ao confessar a mãe, Derrida não a está desmaterializando e transformando-a empura representação? Naturalmente, se considerarmos que até muito recentemente a maioria das obras literárias — não só no Brasil, mas no mundo todo- era escrita quase exclusivamente por homens, é possível dizer que as mulheres têm sido representadas muito mais freqüentemente do que elas têm podido representar. Não é de se admirar que o poeta Coelho Neto (1865-1934), apoiado por seu gabarito de poeta e

\footnotetext{
${ }^{1}$ Esta passagem é citada por Nancy Miller no ensaio "Representing Others: Gender and the Subject of Autobiography." Continuando a discussão do texto de Derrida, Miller afirma que "this retrospective reproduction - recreating the mother after her death, or even in the future perfect, when she will have died-is precisely self-serving” ("esta reprodução retrospectiva—a recriação da mãe depois de sua morte, ou mesmo no futuro perfeito, quando ela terá morrido — éprecisamente auto-justificativa”)— e este processo "serves to construct the self" ("serve para construir o eu") (11, as traduções são minhas).
} 
de homem, arroga-se o poder de ler e interpretar o que a maternidade é e o que ela significa para seus leitores homens e mulheres: "sofrer num paraíso".

Mas o que acontece quando as posições se invertem e a mulher confessa o homem? Mais precisamente, já que esta discussão começou com o texto de um filho confessando sua mãe, o que acontece quando a mãe confessa o filho? No texto de Derrida, ele se apropria da voz da mãe e a confessa como se ela já estivesse ausente, morta. Na tradição latinoamericana, há o caso exemplar da figura da La Llorona que, no mito, perambula pelas margens de rios chorando desesperadamente pela morte de seus filhos. Sua existência, sinônima de seu sofrimento, é a confissão da morte dos filhos. Por ser mãe, e mãe que perdeu seus filhos, a Llorona funciona como um aviso do que pode acontecer a uma mãe que não se dedica totalmente à missão representada de ser mãe. Mas a Llorona mítica tradicional não fala: ela se transformou em um fantasma que é incapaz de articular, com voz humana, a profundidade da sua dor, ou do seu remorso. Ela não é como Derrida, que pode confessar sua mãe; a Llorona só pode chorar e perambular eternamente. Por ter sido suprimida, sua voz é apropriada como símbolo do que o erro de uma mãe pode causar aos filhos.

Mas as mães podem confessar, e às vezes confessam não somente seus filhos, mas também seu relacionamento com o casamento e responsabilidades impostas a elas pela maternidade. Os cinco romances da escritora brasileira Lya Luft, As parceiras (1980), Aasa esquerda do anjo (1981), Reunião de família (1982), O quarto fechado (1984) e Exílio (1987) são um excelente exemplo dessas confissões e das circunstâncias que levam mães a confessar. Diferente de Derrida com sua mãe moribunda, as personagens de Luft não necessitam "avançar no tempo", ou mesmo de evocar memórias antes que elas sejam memórias; em todos estes romances a confissão acontece somente quando o filho já está morto. A voz da mãe aparece, portanto, em um momento quando sua maternidade parece ter sido tirada dela pela morte, e sua confissão se transforma em um momento no qual ela tem que interrogar as razões de sua própria existência. Nestes cinco romances a mulher aquela que dá a vida que será tirada pela morte— articula, une sua voz às vozes de outras mães em outros romances, assim formando um coro que atinge estatura mítica. As histórias dos romances de Lya Luft podem ser vistas, pelo menos inicialmente, como histórias arquetípicas nas quais a memória, o saber e a identidade são apresentadas. O momento da confissão, que se torna possível com a morte do filho, se torna também um momento de extrema dor, desespero e medo. E é precisamente neste momento, quando a mulher enfrenta a si mesma e ao reflexo de si mesma, que mito e ideologia se juntam no texto de Luft. ${ }^{3}$

${ }^{2}$ O poema "Ser mãe” ( Ser mãe é desdobrar fibra por fibra/ o coração! Ser mãe é ter no alheio/ lábio que suga, o pedestal do seio,/onde a vida, onde o amor, cantando, vibra./ Ser mãe é ser um anjo que se libra/ sobre um berço dormindo!/ É ser anseio,/é ser temeridade, é ser receio,/ é ser força que os males equilibra!/ Todo o bem que a mãe goza é bem do filho,/ espelho em que se mira afortunada,/ Luz que lhe põe nos olhos novo brilho!/ Ser mãe é andar chorando num sorriso!/ Ser mãe é ter um mundo e não ter nada!/ Ser mãe é padecer num paraíso! ) é um dos poemas mais populares sobre mães no Brasil, tendo sido recolhido por Afonso Telles Alves na Antologia de Poemas Brasileiros (168) de onde o cito. Nesta mesma Antologia, dois outros poetas, Martins Fontes (1884-1937) e Hermes Fontes (1888-1930) também têm poemas sobre mães, nos quais eles exaltam a proteção, a graça, a dedicação, a doçura, que elas representam, "ainda que mortas."

${ }^{3}$ Esta preocupação com a posição da mulher, especialmente da mãe, na sociedade, não se restringe à obra de Lya Luft. Na literatura brasileira Clarice Lispector, Rachel de Queiroz, Lygia Fagundes 
No entanto, parece incrível que neste momento histórico presente, quando quase no mundo inteiro as mulheres obtiveram o direito de participar na vida social, artística, política e profissional de suas sociedades, as mães nos romances de Lya Luft_Lloronas brasileiras, Maters Dolorosas tropicais - tenham tal poder de atingir os leitores. ${ }^{4}$ Os romances, que podem ser lidos como versões ligeiramente diferentes da mesma história, parecem dizer que o acorrentamento das mulheres ao seu útero e a sua redução à posição de mães eternamente reduzidas às lágrimas, têm um preço. Embora estas mulheres não possam se libertar da estrutura que as coloca na posição de eternas mães, Lloronas condenadas e ser um símbolo de perda, derrota, abandono e morte, elas ainda podem lutar. Assim como Derrida luta contra a morte confessando sua mãe moribunda, as personagens femininas de Lya Luft lutam confessando seus filhos, e assim transformando-os em objetos de representação, desde que estes filhos são o símbolo daquilo que as acorrentou a uma maternidade e domesticidade que elas não puderam evitar. Este é um momento utópico e distópico ao mesmo tempo: livre pela primeira vez da figura do pai, do marido e do filho, as mulheres lançam um olhar ao seu passado e a si mesmas, em busca de uma resposta à pergunta que as seguiram por toda avida. Este é também um momento de extrema dor pela perda da criança—do filho—amado. A dor é expressa no grito de cada uma das mães, de Anelisa em As parceiras, à mãe de Gisela em A asa esquerda do anjo, a Evelyn em Reunião de família, a Renata em O quarto fechado, à Velha em Exílio. Mas é também este momento de suprema dor que lhes permite avaliar suas vidas e repensar o seu sentido mais profundo.

1

Se o mito da Llorona, como outros mitos, se baseia em "questions or birth, sexuality and death” — “questões de nascimento, sexualidade e morte”- (Eagleton 188), então nestes romances a obsessiva presença de mães chorando a morte de seus filhos ressalta a sexualidade da mulher que, precisamente por ser o veículo da vida, também se transforma em veículo da morte. O espaço para a ideologia é representado pelo sistema que determina que a sexualidade feminina tem que, necessariamente, produzir um filho. De fato, a

Telles, por exemplo, escreveram sobre o assunto e produziram contos e romances extremamente importantes para o entendimento das implicações do casamento e da maternidade. Para um estudo mais detalhado sobre a maternidade na obra de Lispector, veja por exemplo Naomi Lindstrom, Lúcia Helena, Earl Fitz, and Marta Peixoto. Joanna Courteau e Renata R. Mautner Wasserman têm ensaios sobre a maternidade na obra de Rachel de Queiroz; Richard L. Brown e Peggy Sharpe discutiram o assunto na obra de Lygia Fagundes Telles.

${ }^{4}$ Na sua entrevista com Judith Payne, Lya Luft diz que até empregadas domésticas lêem e entendem seus livros. Ela continua: "They may not be able to interpret and capture what an intellectual would, but they understand the story and they can read it and this gratifies me very much" ("Elas podem não ser capazes de interpretar e capturar o que um/a intelectual pode, mas elas entendem a história e elas podem lê-la, e isto me gratifica muito”) (108). De fato, a linguagem dos romances de Luft é bem simples, embora seja extremamente elegante. Quando Luft diz que até mesmo as empregadas domésticas - em geral as mulheres menos educadas e as mais exploradas no Brasil—podem entender suas histórias, ela pode estar sugerindo que as experiências vividas pelos seus personagens pretendem a uma tradição que é conhecida por todas as mulheres brasileiras, independentemente de educação e classe social. 
maternidade, tanto na sua realização na forma de filhos, como na negação em esterilidade, abortos ou morte, representa o espaço através do qual cada personagem feminina tem que passar antes que ela possa descobrir quem ela é e o que ela representa na sociedade. A repetição da mesma sina para as heroínas de Luft pode ser lida como a problematização da biologização institucionalizada do papel da mulher na sociedade. Em sua discussão sobre maternidade e domesticidade em literatura, Pamela Ryan escreve que

It has been a common assumption, endorsed by cultural ideologies of femininity, that women find fulfilment in bearing and raising children. Traditionally, it is as though women's 'natural' function is to become mothers, and, conversely, those women who do not have children, either because they are unable to, or because they choose not to, are classified as abnormal, unnatural, or deprived. (124)

é uma suposição comum, confirmada pelas ideologias culturais sobre a feminilidade, que as mulheres conseguem sentir-se realizadas ao gerar e criar filhos. Tradicionalmente, é como se a função "natural" das mulheres seja a de tornarem-se mães, e, da mesma forma, aquelas mulheres que não têm filhos, tanto porque elas são incapazes ou porque elas escolhem não tê-los, são classificadas de anormais, desnaturadas ou deficientes.

Isto quer dizer, então, que a normatização do papel da mulher aponta claramente para o seu “dever” de se tornar, primeiro, uma esposa, e segundo, como um resultado natural, uma mãe. Ser esposa e mãe são então as condições para que uma mulher se sinta completa no mundo. Porém, como os textos de Luft mostram, há uma profunda contradição entre esta “maternidade necessária” e os outros desejos e aspirações de uma mulher. Na ficção de Luft esta contradição se resolve —ou é exposta— com a morte do filho.

É importante notar, aqui, apesar de todas as histórias serem situadas na classe média brasileira, em algum momento do enredo a heroína acaba parecendo-se muito com $L a$ Llorona da mitologia mexicana: a mãe sempre perde um filho, vai para um lugar de onde há água (geralmente a praia), e lá ela chora desesperadamente enquanto revisa sua vida, suas falhas e sua culpa. Esta é exatamente a situação da Llorona do folclore mexicano. A diferença, neste caso — como atestam as inúmeras versões da lenda—é que a Llorona não tem nenhum controle sobre a reconstituição de seu passado.

Luft não é a única escritora a discutir a maternidade e a morte de filhos. Este assunto, presente já na literatura da Grécia antiga (onde encontramos Medéia, que mata os filhos para vingar-se do marido), aparece em muitas outras literaturas. Um dos exemplos mais conhecidos dos leitores norte-americanos, por exemplo, é Sethe, que mata a filhinha Beloved para salvá-la de uma vida na escravidão (Toni Morrison, Beloved). Nestes dois casos, entretanto, a mãe é a agente da morte da criança. Nos romances de Luft, por outro lado, a mãe nunca está diretamente envolvida na morte, mas o seu remorso parece sugerir que ela inconscientemente quer o desaparecimento do filho. Para a mulher-mãe no texto de Luft, é como se este sentimento de perda fosse uma condição básica para a sua própria existência: a mulher só pode sentir-se como tal quando é infeliz, quando está dilacerada pela morte de seu filho. Contudo, estas histórias não estão situadas em uma sociedade mitológica, ou um ambiente irreconhecível. Cada história acontece numa sociedade brasileira reconhecível, com a qual até pessoas com uma educação elementar podem se identificar. Este 
reconhecimento inicial, assim como a identificação com a história e os personagens facilitam a conexão entre mito e ideologia.

Quer dizer, a insistência no tema da mãe que se lamenta e chora é tão intensa que é possível deduzir que estas personagens são uma maneira para Luft demonstrar que a mulher é uma construção retórica sobre a qual a sociedade escreve a si mesma, suas leis, suas recompensas e seus castigos. Ou, lembrando Derrida, a mulher é o espaço onde o filho se confessa. Mas aqui nestes romances, porque o filho está morto (ou louco), a mulher-mãe, não tendo ninguém para confessá-la, se vê diante de duas opções: ou ela admite a perda total de suas funções vitais e morre, ou ela se recria ao confessar o filho. Então, as histórias se transforman no que parece ser o infindável espetáculo de maternidades fracassadas e vazias. Como se elas estivessem para sempre destinadas à derrota, estas personagens escolhem o caminho em que seu amor é negado, seu desejo nunca é reconhecido e suas carreiras são abandonadas: elas depositam tudo no altar do casamento e maternidade. Os personagens de Luft parecem ser a personificação de uma das perguntas de Julia Kristeva em "Stabat Mater":

If it is not possible to say of a woman what she is (without running the risk of abolishing her difference) would it perhaps be different concerning the mother, since that is the only function of the "other sex" to which we can definitely attribute existence? (161)

Se não é possível dizer de uma mulher o que ela é (sem correr o risco de abolir sua diferença) seria talvez diferente em relação à mãe, já que esta é a única função do "outro sexo” à qual podemos definitivamente atribuir existência?

Realmente, mesmo que nós não possamos dizer o que uma mulher é, nós podemos pelo menos provisoriamente- dizer que ela é uma mulher de uma sociedade específica, e que ela obedece a leis, encontra obstáculos e goza prerrogativas entendidas como suas nesta sociedade. No caso de Luft, as personagens são mulheres brasileiras, vivendo sob a construção ideológica que tem sido tradicionalmente chamada patriarcado. Sob as regras desta construção, a mulher é aquela que é esposa e mãe; como todos os romances de Luft dramatizam, qualquer outra coisa que ela queira ser além disso tem que ser secundário aos seus deveres de esposa e mãe. Mas os romances insistem que o desejo e o amor por outra mulher, ou a negação do papel da esposa não podem ser totalmente esquecidos. Em cada romance, as personagens de Lya Luft se rebelam contra as leis e os ditames que lhes são impostos. Não é estranho, portanto, que para todas estas personagens femininas chega o momento em que elas têm que enfrentar a derrocada de seus casamentos e a morte de seus filhos. Parece, então, que a morte destes filhos — nunca das filhas — funciona como um ato de revolta contra a sociedade que as força a "frutificar". 5

\footnotetext{
${ }^{5}$ Embora as filhas sempre sobrevivam, Ella (O quarto fechado) é uma filha que é exemplarmente punida por sua desobediência. Ella e Martim quase cometem incesto quando tentam fugir juntos para se casarem sem o consentimento de Mamãe (que é a madrasta de Martim e mãe de Ella). Quando está tentando fugir, Ella tem um acidente que a deixa aleijada para sempre. Martim é punido mais tarde com a morte de dois filhos, Rafael e Camilo.
} 
Mas a morte do filho tem outro efeito: agora livre de um papel predeterminado, estas mulheres não têm outro recurso senão olhar para trás e revisar suas vidas. Se elas olharem para diante, verão que a página seguinte está em branco; elas não sabem o que escrever nesta página, elas não estão preparadas para escrever nesta página. Esta é a razão para a existência de tanta loucura nos romances de Lya Luft, já que a loucura se transforma no substituto do papel de esposa e mãe para Catarina (As parceiras), Gisela (A asa esquerda do anjo), Ella (O quarto fechado), e para a Velha (Exílio). ${ }^{6}$ Este é o momento quando a mulher enfrenta o "abismo", a "cambaleante vertigem" a que Kristeva se refere em "Stabat Mater". Realmente, como os romances continuamente dramatizam, separar-se do filho significa, para a mãe, ser restaurada "cut in half, alien to its other - and a ground favorable to delirium” (“Stabat Mater”, 179).

Este momento de delírio é perigoso para todas as personagens femininas. Agora sem o filho, a mulher tem que perguntar, como Gisela o faz no fim de A asa esquerda do anjo, “Qual é o meu nome? Onde fica o meu lugar? Como se deve amar?” (141). Estas perguntas expõem os problemas básicos de suas vidas: agora sem ter a identidade de esposas e mães, elas não sabem o que mais elas podem ser, como amar, ou onde viver. Apesar de tudo, elas fazem as perguntas, tremendo de medo, arrasadas com suas perdas, acabrunhadas de culpa. Ao fazer as perguntas cada personagem põe em movimento outras perguntas sobre seu lugar na sociedade, seus papéis não apenas como mães, mas como seres humanos, como mulheres. Mas o eco da última pergunta de Exílio - “Quem sabe?”- pode ser entendido não como uma pergunta, mas como uma sugestão de que, talvez, embora existam suficientes razões psicológicas, históricas e sociais para explicar a história da vida destas mulheres, a resposta talvez tenha que ser procurada no nível mitológico, no qual a maternidade sempre esteve embebida.

“La Llorona” é um mito que, como Tey Diana Rebolledo escreve, juntou lendas do folclore indígena e espanhol: "In both cultures there were prevalent images of women whose children had been murdered, or who themselves murdered or abandoned their children and could not rest thereafter” (62). Rebolledo continua que o mito sincrético de La Llorona conecta

\begin{abstract}
both the Spanish medieval notions of ánimas en pena, spirits in purgatory expiating their sins, and to the Medea myth. She was also closely identified with the pre-Columbian Aztec cultural heroes such as Mocihaquetzque, valiant woman who died in childbirth (and who were the only Aztec women to achieve afterlife in the place of warriors). (63)

tanto as noções espanholas medievais das almas penadas, espíritos no purgatório pagando seus pecados, e o mito de Medéia. Ela também estava intimamente identificada com heróis astecas pré-colombianos tais como Mocihaquetzque, mulheres valentes que morriam no parto (e que eram as únicas mulheres astecas a atingirem a vida eterna junto aos guerreiros).
\end{abstract}

No mito asteca, as únicas mães que mereciam a vida eterna eram aquelas que não podiam realmente cuidar de seus filhos, já que elas morriam no momento exato em que se

${ }^{6}$ Carolina, de $O$ quarto fechado, busca refúgio na loucura para proteger-se da dor da perda do irmão gêmeo Camilo, que ela considera metade sua. Carolina, ao reconhecer sua culpa na morte do irmão, junta-se ao grupo de "mães" que choram a perda do filho. 
tornavam mães. Mocihaquetzque personifica, então, as mães perfeitas, precisamente porque elas não podem ser mães: a sua perfeição existe somente como resultado de sua ausência para cumprir suas funções. Se elas tivessem sobrevivido ao parto, o poder do momento sublime de dar à luz teria sido destruído pela feminilidade das mulheres. Na versão espanhola, as “almas penadas” sofrem por causa de pecados cometidos nesta vida; elas terão que pagar por seus pecados e implorar orações até que suas dívidas terrenas sejam pagas. Há esperança para elas, mas somente se alguém agir em seu favor, rezando e pedindo perdão em seu nome. Assim, em La Llorona, as imagens de pecado e salvação se juntam naquela da mãe que chora pela perda de seus filhos.

Há dois pontos importantes nesta versão do mito. Primeiro, a mulher que chora é uma mãe, e segundo, neste caso a "mãe" não simboliza uma fonte de vida nem um símbolo de proteção à vida. Pelo contrário, a figura está intimamente conectada com a morte, e é representada em um momento quando sua maternidade só pode ser configurada como ausência ou destruição daqueles a quem ela deu a vida. Se a Mocihaquetzque asteca só pode conseguir perfeição através da morte, a Llorona só pode alcançar força mítica total com a morte dos filhos. O que realmente importa é o seu desassossego, a sua eterna aflição, o espetáculo da sua dor. Como a mãe de Derrida, imaginada por ele no futuro perfeito de sua morte, La Llorona também se transforma em pura representação, em um significante vazio que pode ser apropriado, interpretado, preenchido.

O ponto mais importante aqui é, naturalmente, a ausência. No mito a mulher-mãe é reduzida unicamente ao seu ser , que vem representar, "marcar presença” por aqueles em cuja morte ela está implicada. La Llorona se transforma, portanto, no signo de uma poética de ausências: dos filhos e da sua maternidade. É como se o filho, que era o símbolo da autenticidade da posição da mulher na sociedade, outra vez a reinscreve como mãe precisamente por morrer e levar com ele a justificação da existência da mãe. Isto é, a continuação da existência da mãe — desta vez como um fantasma, ou como um símbolo de sua falha em criar o filho até a idade adulta - serve como uma maneira de naturalizar e universalizar uma estrutura social em particular (Eagleton 188) que insiste que o papel mais importante de uma mulher é a maternidade. Quer dizer, embora o mito de La Llorona seja, como outros mitos, basicamente a-histórico e pré-histórico, ele serve um propósito óbvio quando usado dentro de uma ideologia que coloca ênfase na manutenção das mulheres dentro do espaço doméstico e longe de outros.

2

Os quatro primeiros romances de Luft podem ser entendidos como estudos de três temas principais: reflexão, liberação utópica e repressão. Estes temas são todos explorados através de personagens e narradoras que são mães ou mulheres que exploraram diferentes possilibidades maternais. Exceto por Gisela, a personagem principal e narradora de A asa esquerda do anjo, todas as personagens principais nos cinco romances passam pela morte de um filho, ou de um menino que funciona como filho. Em todos os romances a personagem principal — que às vezes é também a narradora — tem uma mãe fraca que se ausenta da vida da filha devido a loucura (As parceiras, A asa esquerda do anjo) ou devido a uma morte prematura (Reunião de família, O quarto fechado, Exílio). Destituída de uma figura materna 
forte e positiva para funcionar como mentora durante a passagem à maturidade e à maternidade, estas mulheres ficam reduzidas a um momento em que elas se lembram de outras vidas que não viveram, escolhas que não fizeram, amores que não usufruíram. Mas esta reflexão também traz um pequeno vislumbre de um momento utópico que é perigoso porque ele implica a liberação, o esquecimento de papéis pré-estabelecidos. Este momento de reflexão é como se, em termos mitológicos, a Llorona pudesse parar de vagar, fazer um balanço do que realmente aconteceu com seus filhos, concluir que suas mortes não são sua culpa e que ela também merece descansar e tentar ser feliz. Mas este momento é passageiro: depois de uma pausa momentânea, as personagens de Luft continuam sua penitência, vagando, chorando, produzindo e consumindo o espetáculo de sua dor, como se estas fossem as únicas razões pelas quais vale a pena viver. Contudo, embora pareça que houve um retorno ao estado inicial, para cada personagem nos textos de Luft este momento de extrema dor tem uma função positiva, porque é só através dele que ela pode ver, ainda que de relance, o que poderia ter sido sua vida.

O primeiro romance, As parceiras, temos o exemplo dos três temas. Em um dado momento da história Anelise - a narradora — vêuma mulher desconhecida mas ligeiramente familar caminhando na praia. A mulher tem um corpo de menina e usa um vestido branco longo e um chapéu. A curiosidade sobre a identidade desta mulher afasta Anelise de suas penosas memórias de sua família, de seu marido, e da morte de seu único filho. Nas últimas linhas da história, a mulher vestida de branco, cuja identidade não é revelada no texto, toma a mão de Anelise, que diz: “De repente, sei quem é. Não entendo como não a reconheci antes. Então era por mim que ela estava esperando, todo este tempo" (141). Como as duas “descem de mãos dadas”, pode-se dizer que Anelise é jovem again, é consolada de suas perdas, está feliz. Este final de As parceiras lembra um poema no livro Mulher no palco, que Luft publicou em 1984:

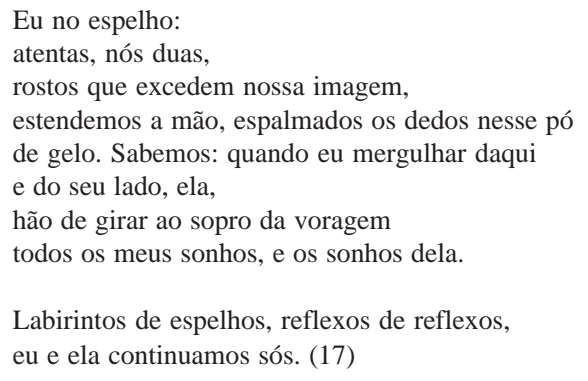

É importante, no contexto tanto do romance quanto do poema, que a narradora não dá nome ao reflexo, precisamente porque ela é este reflexo. O "labirinto de espelhos" onde Anelise se encontra aprisionada mostra reflexos de outras mulheres na família — começando pela avó Catarina, casada à força com um homem brutal que a viola e força a gravidezes constantes - sua própria mãe e tia (privadas da mãe devido à loucura de Catarina, e de pai devido à brutalidade dele); sua única irmã cujo marido a ameaça com divórcio se ela engravidar. Todas estas mulheres, unidas na dor comum e inevitável da maternidade, estão 
isoladas umas das outras por esta mesma dor. A avó Catarina finalmente rejeitara o marido, refugiando-se no sótão, onde ela se vestia totalmente de branco e brincava com bonecas até o dia em que se atirou da janela e morreu no jardim, "caída no canteiro, entre flores amassadas e morangos feitos manchas de sangue, era uma flor a mais, branca" (As parceiras 141-2). A mãe de Anelise, Norma, morre com o marido em um acidente de avião e deixa as duas filhas aos cuidados da irmãs Beata e Dora. Depois de um romance platônico com o filho adotivo de sua tia Dora, Anelise se casa e tem um filho. Depois de várias tentativas, ela finalmente consegue dar à luz um menino, Lalo, que morre dentro de dois anos sem nunca ter aberto os olhos. Depois da morte de Lalo, Anelise busca refúgio na casa de praia onde ela costumava passar os verões com seus pais e sua melhor amiga, Adélia.

É na casa de praia, perto do som das ondas, que Anelise confronta os reflexos da avó louca e da mãe melancólica com os seus; também é aqui que ela reflete sobre o maior amor de sua vida, Adélia, que morreu caindo das pedras no mar quando ambas tinham doze anos. É esta perda do seu primeiro amor que organiza suas outras perdas. Com a morte de Adélia, Anelise diz, "A morte entrou em mim como um ferimento que jamais sarava, pois logo outra pessoa morria, e eu a enterrava naquele lugar ... um buraco enorme, aquele” (24).

No romance $O$ quarto fechado, de 1984, Renata confronta a morte do filho, Camilo, na mesma casa da fazenda onde ela viveu feliz quando jovem e apaixonada por Martim. O romance consiste das horas da vigília antes do enterro, enquanto Renata e Martim se sentam ao lado do caixão do filho, revêem cenas de seu casamento, e lembram os erros do passado. Ainda uma vez, a narrativa é organizada principalmente sob o ponto de vista de Renata, que abandonou uma vida de pianista profissional para casar com Martin. Aqui neste romance, a reflexão, assim como os reflexos, são predominantes.

No Brasil, como o corpo é geralmente enterrado dentro de 24 horas depois da morte, as horas da vigília são compactamente dramáticas. Em $O$ quarto fechado, porque os personagens permanecem no mesmo espaço, o quarto onde o corpo de Camilo está sendo velado, parece que as paredes estão cobertas de espelhos onde os personagens não podem evitar verem-se a si mesmos e aos outros por diversos ângulos. Então Martim relembra sua brutalidade com Camilo por ele ser "efeminado". Por sua vez, Renata vê sua vida com Martim. Ele a amava tanto, mas não não pôde compreender que ela era uma artista, e forçoua a abandonar a música. Ela também vê sua relação com seus filhos gêmeos, Camilo e Carolina. Por fim, ela revisita o seu medo quando os gêmeos nasceram e ela confessou ao seu médico: "Acho que nasci sem os instintos naturais das outras mulheres ... Mesmo antes de engravidar vinha sentindo: o casamento fora um erro. Por mais que tivesse amado Martim, ansiava dolorosamente pela música: era essa a sua vida” (43). Agora, quando Camilo está no caixão, morto debaixo dos cascos de um cavalo (em uma morte que parece demais com suicídio para não ser suicídio) Renata relembra seu outro filho morto, o bebê Rafael, chamado carinhosamente “o anjo Rafael”, que os gêmeos mataram enquanto ela tocava o piano, surda à comoção do lado de fora da porta. E Renata lembra também Ella, a filha da madrasta de Martim, que passa a vida deitada numa cama, num quarto perdido num dos cantos da casa.

\footnotetext{
${ }^{7}$ Na última cena do romance, quando o caixão de Camilo vai ser retirado da casa, ouve-se a voz de Ella pela primeira vez, arrebentando-se em uma risada monstruosa que arrepia a todos os presentes (132). É interessante observar, aqui, que "Ella" não é um nome brasileiro comum. No contexto do
} 
Neste romance a reflexão também pode ser vista em termos da sexualidade dos gêmeos. Carolina e Camilo são idênticos, e, mesmo quando já são jovens adultos ainda dormem no mesmo quarto e têm uma relação incestuosa. Camilo, o texto explica, traz para casa um jovem bonito, por quem está apaixonado. Carolina aproveita a ausência do irmão para atrair o jovem para o quarto. Quando Camilo vê sua irmã com o jovem, sai correndo da casa, monta o cavalo mais bravo da fazenda e é morto pelo animal. Depois da morte, Carolina lembra a reação do irmão quando a viu com seu amante. A narração diz, como se fosse Carolina: “Agora, quem possuía Camilo era a fria Dama que começava a corrompêlo com seu toque obsceno, atingindo Carolina também, na última fibra que a prendia à sua outra parte. A vida: serpente voltando para dentro de si mesma, começo e fim, masculino e feminino, prazer e destruição” (125). Incapaz de deixar que esta “última fibra” se desfaça, Carolina a procura em si mesma, acabando por cortar os cabelos para ficar totalmente igual ao irmão morto.

Diferentemente dos outros romances, no final de A asa esquerda do anjo não há morte, mas um nascimento. Esta é a única novela cuja protagonista, Gisela, não chora a morte de um filho. Ela é uma virgem que se recusa a casar-se com o homem que ela mesma e sua família acham que seria o marido ideal. O pai de Gisela é filho de uma família alemã, nascido no Brasil; a mãe de Gisela é nordestina —e o nordeste brasileiro funciona aqui como o espaço do “não branco”. A tensão entre as coisas “brasileiras” e “alemãs”-língua, comida, cultura - formam o espaço no qual Gisela luta para se encontrar, para descobir quem ela é, quem ela ama, e como entender sua própria identidade, já que ela é rejeitada tanto pelos "brasileiros” por ser “alemã”, como pela tirânica avó paterna por ser "brasileira”, ter a pele escura, falar alemão incorreto, não ser artística como a sua prima Anemarie. O filho morto na história é o seu irmãozinho que funciona como um outro de Gisela, porque era louro e branco como o pai. O menino morto é um aviso constante de que ele, mais branco, mais ariano, merecia estar vivo em seu lugar.

Mas Gisela tem um outro reflexo: a prima Anemarie. Este outro é diferente em tudo: ela é loura, branca, artística e fala alemão corretamente. A avó a adora e a família a idolatra. Gisela diz: "contemplar Anemarie foi como pressentir a possibilidade da beleza absoluta" (72). Mas Anemarie foge com o marido da tia e cai em desgraça aos olhos da família. Ela só vai voltar à casa da avó quando, morrendo de câncer uterino, não tem mais onde buscar refúgio. Mas a avó não a perdoa e cospe na frente do caixão que leva seu corpo dizimado pela enfermidade (117). O câncer, ao mesmo tempo uma doença real e uma metáfora para o seu pecado, claramente aponta para a parte do corpo — o útero- para dizer que ao sucumbir ao desejo e roubar o marido da tia, Anemarie obteve eterna condenação física e moral.

Neste ponto, os fios que prendem Gisela à vida se tornam soltos: em uma seqüência rápida, ela perde a mãe, Leo e a avó. Sozinha na casa com seu pai, as memórias de felicidade para Gisela estão para sempre fixas na imagem da prima Anemarie, que tocava o violoncelo como se estivesse abraçando um amante. Na seqüência final do romance, Gisela está sozinha em seu quarto, sentindo que há um monstro dentro dela: “nem querendo poderia voltar atrás,

romance, como a voz de Ella só se ouve quando há a horrível morte do único filho, seu nome pode ser uma referência a “ela” — a morte, cujo nome geralmente se evita pronunciar. 
como num parto: a mulher não pode recolher o filho, fechar o corpo ... somos como dois bichos acuados. Um embutido no outro" (138). E finalmente, quando a criatura sai de seu corpo, Gisela faz um esforço enorme para encará-la: “Ali está ... a pele esticada ... É enorme. Enrodilhado, tem duas pontas iguais... Não tive um filho de Leo, não abri minhas pernas, mas pari esta criatura” (140). Nas útimas linhas do romance esta criatura vai, se vira e encara a Gisela que, transida de terror, grita: “qual é o meu nome? Onde fica o meu lugar? Como se deve amar?” (141).

Para Gisela, brasileira e filha de pai alemão, o peso da identidade é somado à culpa que ela sente por achar-se incompleta tanto alemã quanto brasileira. Some-se a este sentimento a repressão do desejo que sente pela prima Anemarie. Não é de se admirar, portanto, que a criatura a quem ela “dá à luz” no fim da história, e a quem ela chama de sua identidade, é um monstro. Como uma combinação de partes diferentes que não se misturaram harmoniosamente, Gisela é uma mulher que não pode jamais aceitar o reflexo de sua imagem a não ser como a imagem de um monstro. $\mathrm{O}$ amor que ela sente, quando ele ousa dizer seu nome, chama a si mesmo de monstruoso porque é assim que a sociedade o chama. Gisela é então uma Llorona que chora pela morte não só de toda sua família e da mulher que ela ama, mas também pela aniquilação de sua identidade. Por isso, a horrível criatura que "sai de seu corpo” no fim da história é a re-criação desta identidade, que Gisela tem que esconder e só deixar que saia quando ninguém pode vê-la.

Os temas de vidas não vividas e amores não aceitos aparecem também em Reunião de família. No fim do romance, a narradora Alice vê sua imagem refletida nos olhos de outra mulher. Nesta reunião de família, a cunhada Aretusa, Alice, o irmão Renato, o pai, a irmã Evelyn e seu marido, todos estão passando o fim de semana juntos. A reunião foi organizada pelo marido da irmã, que teme que Evelyn esteja enlouquecendo depois da morte do seu único filho. $\mathrm{O}$ fim de semana se torna, então, uma ocasião para ajustes de contas: cada um dos participantes da reunião vê reflexos deles mesmos e de suas relações com os outros. Todos estão arrasados com a morte do filhinho da irmã; esta dor os deixa vulneráveis e os leva a revelar uns aos outros os abismos de seus fracassos, pecados e desejos. É como se, instigados pelo espetáculo do sofrimento da irmã, cada um se torna em uma versão da figura da La Llorona. Cada um se torna um símbolo do que acontece quando uma criança morre, um amor é rejeitado, ou uma vida é abandonada. E, nesta história, cada pessoa confessa as outras: no clímax, as vidas de todos são reveladas, velhas feridas expostas e velhas contas ajustadas. O pai acusa o filho Renato de ser um fracassado. Alice acusa Aretusa de ser má esposa para seu irmão, e responsável pelos fracassos dele. Aretusa então revela que ela e Alice haviam sido amantes, e que Alice é uma esposa fria e uma mãe indiferente. Quando Evelyn intervêm para consolar Alice, as duas irmãs brigam e trocam acusações, algumas das quais datando de quando a mãe morreu e os deixou aos cuidados de um pai que não os amava e uma babá ignorante. É esta personagem, a babá que criou os três órfãos e ainda vive na casa como empregada, quem vai fazer a revelação mais chocante da história: em seu pequeno quarto Alice encontra álbuns de figuras pornográficas de mulheres nuas. O lesbianismo reprimido da babá, refletido no amor rejeitado de Aretusa e Alice, se torna um símbolo dos problemas que atingem a todos os membros da família. Como Gisela em A asa esquerda do anjo, os personagens de Reunião de família também não podem encarar suas identidades, porque eles temem sua mostrosidade. 
Estes personagens parecem ser estudos para “faces que excedem sua própria imagem”, como Luft diz no poema citado antes; eles vivem em um labirinto de espelhos, mas coninuam sozinhos. O momento utópico, seja ele o reconhecimento da humanidade essencial que os une a este outro além da superfície do espelho, seja ele a compreensão de um nível além do humano, só é esboçado ligeiramente em dois romances, Reunião de família e Exílio. Nos dois casos, este momento utópico é relacionado com um tempo e espaço que só podem ser localizados fora do tempo e do espaço. Ou então, paradoxalmente, o momento utópico também pode ser relacionado com um tempo, agora passado, quando os personagens poderiam ter intervindo em suas vidas, tomado novas direções, ou assumido publicamente um amor que a sociedade não aprova. ${ }^{8}$ Este amor reprimido — por outra mulher, ou homem, ou por uma carreira - finalmente se revela quando os personagens, enfraquecidos pela dor, não conseguem negá-lo. Mas então pode ser tarde demais.

Ou, como Exílio sugere, pode ser o começo. Na metade do romance, a narradora pára sua própria história para contar a história da Velha, outra moradora da Casa Vermelha, onde a narradora está passando um período de retiro. A história da Velha condensa, de forma dramática, muitos dos temas já explorados nos romances anteriores. A personagem, "uma velhinha discreta, cabelos de algodão metido numa redinha transparente, com minúsculas contas azuis” (83) uma vez foi uma mulher de classe média confortável, cuja vida calma e despreocupada a levou ao pecado. A Velha, sem outro nome na história, enlouqueceu muitos anos atrás, quando seu filhinho morreu afogado no mar. Na ocasião ela estava passando o verão sozinha com os filhos, já que o marido estava muito ocupado para acompanhá-la nas férias de três meses. Durante este período, ela se apaixonou por outro homem, e um dia deixou o filhinho dormindo e foi encontrar-se com o amante na praia. Quando ela voltou para casa, os vizinhos estavam procurando o menino, que havia desaparecido. Com as pernas ainda cobertas de sêmem e areia, ela enlouquece de dor e culpa. No dia seguinte, quando alguém a banha, sua pele está cheia de feridas e, entre as pernas "tinha o cheiro acre do sexo que a penetrara tantas vezes; pele coberta pela saliva do demônio. E no coração trazia, para sempre, a morte” (85). ${ }^{9}$

Em Exílio, a morte do filho está conectada com a ausência e não com a premeditação da mãe. Contudo, como a morte do filho ocorre quando a mãe está fora, buscando seu próprio prazer com um homem estranho, o seu pecado -0 esquecimento de suas responsabilidades de mãe- é a causa indireta da morte do filho. O único refúgio para tal

\footnotetext{
${ }^{8}$ Em Reunião de família, há um momento em que Evelyn revela à família que Alice disse ter um amante. Depois do choque de todos, Evelyn ri e diz que sabe que tudo é mentira, que Alice inventou os detalhes sujos do romance só para distraí-la da dor da morte de seu filho. Este falso romance clandestino de Alice obviamente funciona como um reflexo do caso de amor que ela realmente teve com Aretusa quando as duas eram jovens.

9 A história da Velha é similar à versão do mito da La Llorona que aparece em Mexican Ghost Tales of the Southwest. Nesta versão, La Llorona é uma mulher que quer aproveitar a vida: "She longed for the gaiety and the dancing at the fiestas as an escape from her daily responsibilities" ("Ela ansiava pelo prazer e pela dança nas festas como uma fuga de suas responsabilidades diárias”) (Avila 11). A diferença, nesta história, é que no mito a morte das crianças é planejada pela mãe, que os força dentro de um saco e os atira num rio; a Velha não matou o filho, apenas sente-se culpada por não ter impedido sua morte.
} 
pecadora é a sua auto-condenação a uma vida dedicada à lembrança do momento da morte do menino. Para a Velha de Exílio, assim como para todas as personagens principais dos romances de Luft, o sexo é a maior força em suas vidas, a fonte do maior prazer e do mais profundo sofrimento, e também aquilo que lhes trará a morte, ou a alienação das pessoas que mais amam. No caso de Anemarie, de A asa esquerda do anjo, a força do sexo se aninha em seu útero, que adoece com câncer; em $O$ quarto fechado, o desejo pelo sexo com Martim (que está na posição de irmão, já que é filho da madrasta), é a razão da transformação de Ella em um monstro enorme e mudo; no mesmo romance, é também o sexo (ou o desejo de sexo com a irmã) que leva Camilo à morte. Em Reunião de família, é ainda o conhecimento das falsas escapadas sexuais de Alice que dá a Evelyn as armas para destruí-la diante de toda a família.

Se o deleite em sexo é visto como a fonte do mal nos romances de Luft, sua negação não oferece a solução. Em A asa esquerda do anjo, o monstro que sai do corpo de Gisela pode ser entendido como o fruto da sua negação, sua abdicação do sexo. Em As parceiras, a proibição do sexo—entre a avó Catarina e a enfermeira—é a causa de sua morte.

O que conecta os perigos situados no deleite e na rejeição ao sexo é o fato de que todas estas mulheres (mesmo Gisela, que é virgem) são levadas a serem mães. A inevitabilidade de tal destino, assim como a luta para entendê-lo, aceitá-lo ou negá-lo, contamina outros personagens, transpondo até a linha do gênero. O melhor exemplo de dedicação materna em Exílio, por exemplo, é um homem, o amante da narradora, que desiste dela para continuar cuidando do filho retardado. Outro exemplo é o marido de Evelyn, em Reunião de família, que assume o papel de mãe carinhosa para a esposa que está lentamente enlouquecendo depois da morte do filho. Finalmente, em $O$ quarto fechado, Martim tenta assumir o papel da mãe de seus filhos gêmeos quando Renata os abandona depois da morte do menino Rafael. A maternidade em Luft então pode ser entendida como o nome daquilo que é não só inevitável, mas também inevitavelmente destinado ao fracasso

Se o sexo é a fonte de tanto sofrimento, o que estes romances dizem do amor? Nem todo amor pode ser reduzido ao amor que pode produzir um filho. Naturalmente, para a concepção de uma criança, deve haver um encontro heterossexual. No entanto, como vemos no caso da avó Catarina em As parceiras, nem sempre sexo heterossexual significa amor. A pessoa que ela realmente ama, a enfermeira que cuida dela no quarto do sótão, acaba sendo a razão de sua morte. Ainda em As parceiras, Adélia, a amiga de infância de Anelise, morre aos doze anos. O texto parece sugerir que as meninas se amavam e, como Anelise continua dizendo que Adélia foi o grande amor de sua vida, é possível concluir que se Adélia tivesse vivido, elas seriam amantes. Em $A$ asa esquerda do anjo, além dos problemas de sua identidade cultural, Gisela luta toda a vida contra o amor que sente pela prima Anelise, cujo corpo ela relembra nos mínimos detalhes. Em Reunião de família, Alice e Aretusa se amam quando jovens, sufocam este amor e vivem vidas vazias e fracassadas. Em $O$ quarto fechado, Camilo é destruído pelo ciúme da irmã gêmea Carolina, e pela sua homossexualidade que é severamente reprimida pelo pai. Finalmente, em Exílio, mais uma vez o amor de uma pessoa do mesmo sexo é a causa de punição: a Loura, amante da Morena, está morrendo de câncer, e se recusa a fazer quimioterapia para não ficar longe da mulher amada. A sua doença, que é constatada quando ela assume seu amor pela Morena, não pode ser curada, e parece ter sido o resultado do lesbianismo. 
A uma certa altura de "Stabat Mater", Julia Kristeva escreve que "we live in a civilization where the consecrated (religious or secular) representation of femininity is absorbed by motherhood” — “nós vivemos em uma civilização onde a representação (religiosa ou secular) sagrada da feminilidade é absorvida pela maternidade” (16). "Se, entretanto", ela continua, "one looks at it more closely, this motherhood is the fantasy that is nurtured by the adult, man or woman, of a lost territory" — "nós a olharmos mais de perto, esta maternidade é a fantasia nutrida pelo adulto, homem ou mulher, de um território perdido" (161). Se tomarmos por um momento esta última idéia —a maternidade como um território perdido- e a aplicarmos aos romances de Lya Luft, teremos que concordar que, de fato, o território perdido é uma constante em todos eles, mas nem sempre ele pode ser ligado unicamente à mãe. Em As parceiras, ele é a inocência da infância, um tempo em que Adélia e Anelise se amavam e brincavam nas rochas e fingiam que a morte não existia. Em A asa esquerda do anjo, o território perdido é um tempo além da compreensão de Gisela, mas que teria a presença constante de Anemarie e a ausência de conflitos entre suas duas heranças culturais; neste território, a identidade de Gisela, híbrida brasileira e alemã e que ama outra mulher não seria mostruosa. Em Exílio, o território perdido é a mãe da narradora, que se suicidou quando ela era uma criança; e ele é também — visto já no quase futuro perfeito a que se refere Derrida em relação à sua mãe moribunda- é o corpo da Loura para a Morena que a ama e que sabe que vai perdê-la para a morte. Afinal, ainda em Exílio, o território perdido é, para a Velha, o filho que morreu afogado enquanto ela traía o marido com um estranho.

Mas este território poderia ser também uma outra coisa, algo além do humano, e que os romances apresentam aos poucos, em fragmentos, até as páginas finais de Exílio, quando Luft dedica mais tempo ao assunto. Em Reunião de família, no final do romance, quando todos os personagens estão esgotados pelas emoções vividas durante o dia, todos estão sentados à mesa da sala de jantar, quando eles ouvem, "Fora de casa, um rumor como de ramos poderosos inunda o pátio, derrama-se pela janela ... A essa respiração fantástica mistura-se o fervilhar da vida subterrânea, as raízes imortais que expelem sua seiva das profundezas (119, minha ênfase). Já a narradora de Exílio, circundada de loucura e morte na Casa Vermelha, parece chegar ao fim da linha, que pode ser visto também como o começo de outra. Como a Llorona do mito, ela diz, "Não me quis a morte” (200). Mas, em seguida, ela encontra um "regaço transitório, entre essas raízes cúmplices, chão eterno" (200-1). Estas raízes, que se enfiam pelo “chão eterno,” a impelem para diante, através das “correntes da vida e da morte" (201). O que ela está buscando, nesta jornada que se inicia no fim do romance? A mãe? Uma casa? Se for a mãe, depois de tão larga separação, ela pode não reconhecê-la. Se for a casa, quando ela chegar lá, talvez ela não possa ficar.

Esta casa, cuja localização ela não sabe, é a instância definitiva da sua feminilidade. O texto sugere que ela é também a mãe definitiva, em quem ela pode encontrar refúgio e esquecer toda dor. É significante que Luft conclui o romance com um poema que termina: "ah maldita/ ah venerada/ enfim” (201). Os dois adjetivos, "maldita” e "venerada” são femininos. Por esta razão, eles podem se referir a "solidão”, ou a “orfandade”, ou a "vida”, todos substantivos femininos que aparecem na primeira estrofe do poema. "Enfim” ecoa o 
suspiro de alívio do viajante que busca por um abrigo há muito tempo. Este lar, que a narradora de Exílio e todas as personagens de Luft buscam, pode ser o território perdido a que Kristeva se refere. Naturalmente, este “enfim” também pode se referir ao alívio causado pelo fim do sofrimento, pela morte. Por outro lado, como em Exílio e todos os outros romances em que as personagens sofrem pela ausência da mãe morta, o suspiro de alívio pode ser a representação da alegria deste reencontro. Neste momento, quando a mãe e a filha finalmente se reunirem, não haverá necessidade de lágrimas amargas, eternas perambulações às margens de rios, ou mesmo para confissões: todos os pecados serão perdoados, todas as dores esquecidas. Ou, neste "regaço vegetal” de raízes cúmplices, o ciclo da vida pode recomeçar, fertilizado pela vida anterior, que se decompõe no chão eterno. É este o momento utópico primordial da ficção de Luft. Neste momento, não só as personagens dos romances, mas Eros e Thanatos, La Llorona e seus filhos afogados, Derrida e sua mãe, finalmente poderão viver no mesmo tempo e no mesmo espaço, neste caso não mais o futuro perfeito, mas o perfeito presente.

\section{BiBLIOGRAFIA}

Avila, Alfred. Mexican Ghost Tales of the Southwest. Kat Avila, comp. Houston: Arte Público Press, 1994.

Brown, Richard L. "Lygia Fagundes Telles: Equalizer of the Sexes”. Romance Notes 32/ 2 (Winter 1991): 157-42.

Coelho Neto, Henrique Maximiliano. "Ser mãe”. Affonso Telles Alves, ed. Antologia de Poetas Brasileiros. São Paulo: Edigraf, s.d.

Courteau, Joanna. “The problematic Heroines in the Novels of Rachel de Queiroz”. LusoBrazilian Review 22/2 (1985): 123-44.

Derrida, Jacques. Circonfession. Jacques Derrida. Paris: Seuil, 1991.

Eagleton, Terry. Ideology; An Introduction. Londres/Nueva York: Verso, 1991.

Fitz, Earl E. Clarice Lispector. Boston: G.K. Hall and Company, 1985.

"Freedom and Self-Realization: Feminist Characterization in the Fiction of Clarice Lispector”. Modern Language Studies 10/3 (Fall 1980): 51-61.

Helena, Lúcia. “A literatura segundo Lispector.” Revista Tempo Brasileiro 104 (jan.-mar. 1991): 25-42.

Kristeva, Julia. “Stabat Mater”. The Kristeva Reader. Léon S. Roudiez, trad. Toril Moi, ed. Oxford: Basil Blackwell, 1986.

Lindstrom, Naomi. “Clarice Lispector: Articulating Woman’s Experience”. Chasqui; Revista de Literatura 8/1 (1978): 43-52.

Luft, Lya. As parceiras. [1980]. 5 ed. São Paulo: Edições Siciliano, 1990. A asa esquerda do anjo. [1981]. 4 ed. São Paulo: Edições Siciliano, 1991. Reunião de família. [1982]. 4 ed. São Paulo: Edições Siciliano, 1991. O quarto fechado. [1984]. 4 ed. São Paulo: Edições Siciliano, 1991. Mulher no palco. Rio de Janeiro: Salamandra, 1984. Exílio. [1987]. 3 ed. São Paulo: Edições Siciliano, 1991.

Miller, Nancy K. "Representing Others: Gender and the Subjects of Autobiography”. Differences 6/1 (Spring 1994): 1-27. 
Payne, Judith A. “Lya Luft: Fiction and the Possible Selves”. Brasil/Brazil: Revista de Literatura Brasileira 5/4 (1991): 104-14.

Peixoto, Marta. “Family Ties: Female Development in Clarice Lispector”. The Voyage In. Elizabeth Abel, Marianne Hirsch e Elizabeth Lengland, eds. Hanover, NH: University Press of New England, 1983. 287-303.

Rebolledo, Tey Diana. Women Singing in the Snow; A Cultural Analysis of Chicana Literature. Tucson: University of Arizona Press, 1995.

Ryan, Pamela. “A Woman's Place: Motherhood and Domesticity in Literature”. Unisa English Studies 29/1 (1991): 24-34.

Sharpe, Peggy. "Fragmented Identities and the Progress of Metamorphosis in Works by Fagundes Telles”. International Women's Writing: New Landscapes of Identity. Ann E. Brown, et al. Westport: Greenwood Press, 1995. 78-85.

Wasserman, Renata R. Mautner. “A Woman’s Place: Rachel de Queiroz’s Dôra, Doralina”. Brasil/Brazil: Revista de Literatura Brasileira 2 (1989): 46-58. 